\title{
Influential factors on knowledge sharing in banking industry
}

\author{
Hossein Gazor $^{\mathrm{a}^{*}}$, Farhad Koohkan ${ }^{\mathrm{b}}$, Amene Kiarazm ${ }^{\mathrm{a}}$ and Kianoush Nazari Ameleh ${ }^{\mathrm{c}}$
}

${ }^{a}$ Department of Management, Kashmar Branch, Islamic Azad University, Kashmar, Iran

${ }^{b}$ Accounting Department, faculty member of Jahad Daneshgahi Kashmar, Iran

${ }^{c}$ Department of Management and Accounting, Allameh Tabataba'i University, Tehran, Iran

AR T I C L E I N F O AB S T A T

Article history:

Received March 15, 2012

Received in Revised form

March, 15, 2012

Accepted 18 May 2012

Available online

May 212012

Keywords:

Knowledge management

Knowledge sharing

Organizational culture

Trust
This paper presents an empirical study to identify factors influenced on knowledge sharing of employees in organization. With wide literature review in knowledge management, we identify important factors in sharing knowledge including trust, culture, organizational structure, employee's attitude to share knowledge, and motivation method. The survey is based on a questionnaire consists of 25 items to measure the impact of important factors. Research population is selected from state and private bank's employees. The preliminary results show that only organizational structure has not significant impact on knowledge sharing.

(C) 2012 Growing Science Ltd. All rights reserved.

\section{Introduction}

In today's business environments, perception of knowledge plays an important role for organizations (Abili, 2011). Cooperation or collaboration is surely known as a central and effective working means to achieve desired outcomes for an organization. Knowledge is a firm's most valuable resource because it embodies intangible assets, routines, and creative processes, which are difficult to imitate (Renzl, 2008; Grant, 1996). Today's knowledge-based economy knowledge, especially that possessed by individuals, plays a critical role in driving the organization value (Jasimuddin, 2007). By virtue of knowledge sharing (KS) behavior, the most valuable personal knowledge can be transferred to multiple individuals, expanded throughout an organization, and finally help organizations achieve success (Lin, 2008; Subramaniam \& Youndt, 2005; Wang \& Wang, 2012; Tagliaventi et al., 2010; Chen et al., 2012). Consequentially, KS behavior among employees, which enables the element of cooperation, can be of paramount importance in shaping the organization's fortunes (Jiacheng et al., 2010). It is a key process in creating new products and services, in leveraging organizational

* Corresponding author. Tel: +989124354291; fax: +981925222099

E-mail addresses: hossein.gazor@yahoo.com (H. Gazor) 
knowledge assets and in achieving collective outcomes (Boer et al., 2011; Hong et al., 2011). Kim \& Bock (2002) believe that one of the essential challenges and the most difficult part of knowledge management process is to help people share what they know. They put forward two reasons for this statement: 1 . Knowledge has an adhesive property and is steady in people's mind, this inheritance leads to slowness, cost, and unreliability of knowledge transfer among people. 2. Knowledge sharing process is composed of knowledge externalization through knowledge resource and internalization of it by its receiver. As Abili et al (2011) mentioned, from economic perspective, KS issues are noteworthy. According to this point of view, scarcity of knowledge, determines its financial value. In fact, if people are the owner of rare and critical knowledge, they will receive lots of benefits from the organization. The main objective of this paper is to identify factors influence on knowledge sharing in organization. First, knowledge management literature is studied, hypotheses are developed, and then data gathered from population is analyzed.

\section{Literature review}

\section{1. knowledge-sharing mechanisms}

Due to better understanding of factors, which impact on KS, first, we articulate some mechanisms for sharing knowledge, briefly. Cabrera and Cabrera (2002, p. 690) pointed out, the "most extended, yet debated" taxonomy of organizational knowledge distinguished two dimensions of knowledge: degree of articulation and degree of aggregation. There are various ways of categorizing the degree of articulation. Polanyi (1962) differentiated between tacit and explicit knowledge, which refers to the ease in which knowledge can be articulated and communicated to others. Other researchers differentiated between codified and tacit knowledge (e.g., Cowan et al., 2000; Nonaka, 1994; Saviotti, 1998), which refers to the extent of which knowledge has been articulated and captured in documents and databases. The degree of aggregation distinguishes between individual and collective forms of knowledge, or which knowledge is held by one person or embedded in the interactions amongst a group of people (Boh, 2007). Several scholars have examined the interaction between these two dimensions of knowledge (Spender, 1996) to create four types of knowledge: individual tacit, individual-explicit, collective-explicit, and collective-tacit. Boh (2007) identified two dimensions of knowledge sharing mechanisms: codification versus personalization, and individualization versus institutionalization. He mentioned that codification versus personalization distinguishes between mechanisms, which enable the sharing of codified knowledge versus tacit knowledge1. Individualization versus institutionalization distinguishes between mechanisms that enable the sharing of knowledge at the individual level, or at a collective level.

\subsection{Factors Influenced on knowledge sharing}

\section{Trust (T)}

Many scholars have taken "trust" as an important influencing ingredient in KS (Huang et al., 2008; Weir \& Hutchings, 2005; Jiacheng, et al., 2010; Renzl, 2008; Zhang et al., 2006; Abili et al., 2011; Yang, 2010). The concept of trust in management indicates employee faith in an organization's goal attainment and organizational leaders and the belief that organizational action will be beneficial for employees (Kim \& Mauborgne, 1997). Trust in the workplace has been shown to have a strong and robust influence on a variety of organizational phenomena, including job satisfaction, stress, organizational commitment, productivity, and, most relevant to the current research, knowledge sharing (Levin \& Cross, 2004). Abrams et al. (2003 p. 65) suggested that "trust leads to increased overall knowledge exchange, makes knowledge exchanges less costly, and increases the likelihood that knowledge acquired from a colleague is sufficiently understood and absorbed that a person can put it to use". Also, Renzl (2008) mentioned that trust plays a key role in documentation of knowledge. As seen in literature, trust is one of the most important factors in sharing knowledge. 


\section{H1: trust between employees has a positive and significant impact on KS.}

\section{Organizational Culture (OC)}

Culture is a collective programming of the mind, which distinguishes the members of one group from another (Hofstede 1980). It is a broad term, which covers national, ethnic, organizational and professional cultures. Each type of culture shapes the cognition and behaviors of individuals in their daily lives (Xiong \& Deng, 2008). Organizational culture is the shared value and beliefs and shapes the practice of organizational members in the organizations. Organizational culture affects knowledge sharing (Abili et al., 2011; Jiacheng et al., 2010; Yao et al., 2007; Du et al., 2007). For example, Moller and Svahn (2004) examined the impact of ethnic culture on knowledge sharing in various types of intercultural business nets. They suggested that the nature of the cultures involved and the type of network both influence the knowledge-sharing barriers. As shown in the existing research, culture effectively impacts the knowledge sharing process in an organization through (a) the development of a knowledge friendly organizational culture (Jones et al. 2006), (b) adequate consideration of the various kinds of culture involved (Ford \& Chan, 2003), and (c) the application of effective technologies for facilitating the knowledge sharing process. To improve the effectiveness of knowledge sharing process, a better understanding of the role of culture in knowledge sharing is crucial (Xiong \& Deng, 2008).

H2: organizational culture has a positive and significant impact on KS.

\section{Organizational Structure (OS)}

As a firm's organizational structure expands, the respective business units in an organization might not only become competitors of one another internally, but may also be partners if considered from an external perspective (Lin, 2008). Besides, some people consider that the impetus to KM includes not only system and hardware operations but also the design and features of the organizational structure, coordination between organization units, competitive and cooperative relationships among organization units and relational involvement (Gadde \& Snehota, 2000; Lin, 2008). Cooperation in the network is incorportaed in both the structure and the process of developing intra-organizational relationships, especially the exchange of resources and knowledge in the firm (Tsai \& Ghoshal., 1998; Tsai, 2000) shown to yield in better problem solving and improved performance (Takeishi, 2001). Tsai and Ghoshal (1998) suggested that interactive relationships built through the social network are beneficial to facilitate knowledge-sharing activities amongst organization units. Nevertheless, when the organization is becoming more complicated and differentiated and needs more with the formal system and regulatory policies, KS activities may be adversely impacted (Lin, 2008).

\section{H3: organizational structure has a positive and significant impact on KS.}

\section{Employee's Attitude (EA)}

Hislop (2003) in a survey reported that the most imperative item in practicing KS was the question of employee attitude, not the motivation leading employees to share. From the aspect of an employee's behavior, Szulanski (1996) and Yang (2008) disclosed that people ignore the importance of KS. In addition, some individuals possess an 'unwillingness to share' behaviour, because of their insecure feelings, such as the fear of being impeded from moving up and the notion of 'knowledge is power' (Szulanski, 1996). In other words, employees feel fear from the loss of superiority and knowledge ownership after sharing their unique knowledge (Szulanski, 1996; Bartol \& Srivastava, 2002). Some others may not interest in sharing, another people may prefer to work alone, and they are not interested in learning from others. These preferences are because they think that they are experts. As a result, to promote KS the employee's motivation namely, employee's inherent tendency and willingness to share their knowledge, is essential to success (Lin, 2007; Jiacheng et al., 2010). 
H4: employee's attitude has a positive and significant impact on KS.

\section{Motivation Method (MM)}

There are different studies devoted on analyzing KS motivations and impediments (Bock et al., 2005; Hwang \& Kim, 2007; Quigley et al., 2007; Jiacheng et al., 2010). From the human-resource perspective, motivation normally preserves two forms namely, material (external) and non-material (internal). For example: Davenport and Prusak (1998) were of the opinion where it is necessary to incorporate both material and spiritual motivation into an incentive plan, which would only be informative if the forms of motivation are direct. In their study, on the willingness of sales executives of a life insurance firm to share knowledge with their peers, O'Donnell (2003) explained amongst all factors impacting the sales executives' willingness to share knowledge, incentive policies for pleasantness and group performance are the most important, which shall be designed to suit the company's operation and sales incentive policy.

As the focus is on human factors, the primary limitations for efficient KS such as collaboration are associated with human nature and the lack of an adequate motivation policy (Hong et al., 2009). Hong et al. (2011) explained in their research that motivation exhibits a high relative importance to overcome barriers to knowledge sharing. All relationships are shown in Fig. 1. In addition, Table 1 shows some researchers that have focus on these relations.

H5: reward system of organization has a positive and significant impact on KS.

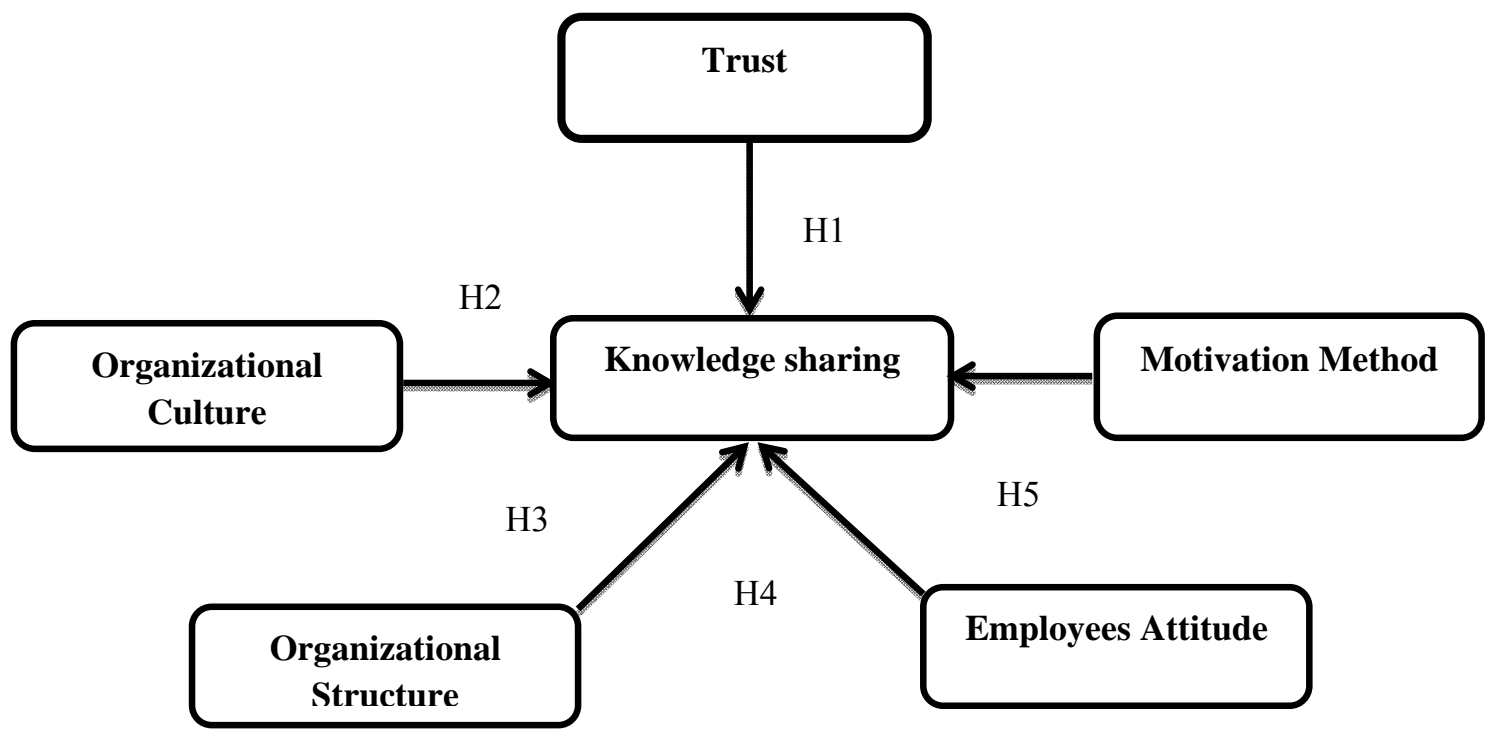

Fig. 1. Relationships among variables

\section{Methodology}

\subsection{Population and Questionnaire}

In this study, we choose zone 1 of Tehran's state and private bank branches for population. For sampling, we used clustering technique and selected fifteen branches from both state and private banks random. We have also selected 7 employees in each branch randomly including chief, assistant, cashier and so on. Therefore, survey sample obtained 210 people. A questionnaire (see Table 1) was developed with 25 items for measuring 5 variables. A 5-point Likert scale $(1=$ totally disagree, $5=$ totally agree) was used to measure the variables. For more confidence, 230 questionnaires were distributed in sample and came back 172 of them. 
Table 1

Items of research questionnaire

\begin{tabular}{|c|c|c|}
\hline Variable & Items & Researcher(s) \\
\hline \multirow{5}{*}{$\begin{array}{l}\text { Knowledge } \\
\text { Sharing (KS) }\end{array}$} & $\begin{array}{l}\text { Employees can freely access to the majority of document, information and } \\
\text { knowledge within organization. }\end{array}$ & \multirow{2}{*}{ Kim \& Lee, 2004} \\
\hline & $\begin{array}{l}\text { Employees voluntarily share individual know-how, effective information and } \\
\text { knowledge with each other. }\end{array}$ & \\
\hline & $\begin{array}{l}\text { Your department uses the various databases frequently to improve the quality } \\
\text { of operation flows involving other departments }\end{array}$ & \multirow[b]{2}{*}{ Lin, 2008} \\
\hline & $\begin{array}{l}\text { Your department has a motivation policy in place for encouraging employees } \\
\text { to make recommendations for improvements and exchange experience with } \\
\text { other departments }\end{array}$ & \\
\hline & $\begin{array}{l}\text { Your department and other department have exchanged knowledge or } \\
\text { experience with other departments on numerous occasions }\end{array}$ & $\begin{array}{l}\text { Lin, 2008; Kim \& } \\
\text { Lee; } 2004\end{array}$ \\
\hline \multirow{3}{*}{$\begin{array}{l}\text { Organizational } \\
\text { Culture (OC) }\end{array}$} & There is a friendly organizational culture. & \\
\hline & $\begin{array}{l}\text { There is a culture of the application of effective technologies for facilitating } \\
\text { the knowledge sharing. }\end{array}$ & \\
\hline & There is cooperation culture between employees of organization. & \\
\hline \multirow{5}{*}{$\begin{array}{l}\text { Motivation } \\
\text { Method (MM) }\end{array}$} & Your department emphasizes material incentives to increase staff morale & \multirow{5}{*}{ Lin, 2008} \\
\hline & $\begin{array}{l}\text { Your department emphasizes the importance of a bonus policy to increase } \\
\text { morale }\end{array}$ & \\
\hline & $\begin{array}{l}\text { Wages and salaries are the most important form of income for employees in } \\
\text { your department }\end{array}$ & \\
\hline & $\begin{array}{l}\text { Your department shows appreciation for employees who have put forward } \\
\text { problem-solving proposals mainly by making a public citation }\end{array}$ & \\
\hline & $\begin{array}{l}\text { Your department stresses the importance of work quality over sales } \\
\text { performance in its staff performance reviews }\end{array}$ & \\
\hline \multirow{3}{*}{$\begin{array}{l}\text { Organizational } \\
\text { Structure }(\mathrm{OS})\end{array}$} & Decision-making method in organization is participative. & \multirow{3}{*}{$\begin{array}{l}\text { Griffen \& } \\
\text { Moorhead, 2001; } \\
\text { Al-Alawi et al., } \\
2007 \\
\text { Syed-Ikhsan \& } \\
\text { Rowland, 2004; } \\
\text { Al-Alawi et al., } \\
2007 \\
\text { Goh, 2002; Al- } \\
\text { Alawi et al., 2007 }\end{array}$} \\
\hline & Information flow in organization is easy. & \\
\hline & Cross-functional teams exist in organization. & \\
\hline \multirow{5}{*}{$\begin{array}{l}\text { Employees } \\
\text { Attitude (EA) }\end{array}$} & My knowledge sharing with other team members is an enjoyable experience & \multirow{3}{*}{$\begin{array}{l}\text { Bock et al., 2005; } \\
\text { Fishbein \& Ajzen, } \\
\text { 1975, 1981; Chen } \\
\text { et al., 2012; } \\
\text { Jiacheng, et al. } \\
2010\end{array}$} \\
\hline & My knowledge sharing with other team members is valuable to me & \\
\hline & My knowledge sharing with other team members is a wise move & \\
\hline & My knowledge sharing with other organizational members is good. & \multirow{2}{*}{$\begin{array}{l}\text { Jiacheng et al., } \\
2010\end{array}$} \\
\hline & My knowledge sharing with other organizational members is harmful. & \\
\hline \multirow{4}{*}{ Trust $(\mathrm{T})$} & Employees have full confidence in the skills of their co-workers. & \multirow{4}{*}{ Kim \& Lee, 2004} \\
\hline & Employees do not try to deceive their co-workers for their own profits. & \\
\hline & $\begin{array}{l}\text { If employees got into difficulties at work, they know their co-workers would } \\
\text { try and help them out. }\end{array}$ & \\
\hline & Employees trust expertise of their co-workers. & \\
\hline
\end{tabular}

\subsection{Reliability and validity}

We analyzed four basic aspects of the scale: its conceptual definition, validity, reliability. The conceptual definition is associated with the theoretical bases considered in the scale development. The measurement scale here was built on the basis of an extensive analysis of the literature, considering research that defines the nature and structure of the concepts under analysis. The validity of a measurement scale refers to the extent to which the measurement process is error-free. The validity of the scale here was confirmed by the content validity. To ensure content validity, a pretest 
of the questionnaire was made by six experts (five researchers in management and a business consultant). We used a reliability coefficient - the Cronbach alpha - to analyze the reliability of the scale. This coefficient evaluates the consistency of the entire scale, and is the most commonly used measure (Hair et al. 2004). The Cronbach alpha is close to 0.84 for all the variables, which confirms the scale reliability.

\section{Results}

\subsection{Demographic results}

The participants were primarily male (73\%). Their ages ranged from 23 to 56 years of age with $77.5 \%$ being $23-35$ years old and $22.5 \%$ being $35-56$ years old. The participants were boss $(8 \%)$, assistant (12\%), cashier (24\%), teller (48\%), and loaning (8\%). Table 2 demonstrates the characteristics of the respondents.

Table 2

Demographic data of population

\begin{tabular}{|c|c|c|c|c|c|}
\hline & Number & Percent (\%) & & Number & Percent (\%) \\
\hline Job title & & & Education & & \\
\hline Boss & 14 & 8 & College degree & 18 & 10 \\
\hline Assistant & 21 & 12 & Graduate & 115 & 67 \\
\hline Cashier & 42 & 24 & Master & 39 & 23 \\
\hline Teller & 83 & 48 & Income monthly (Rials) & & \\
\hline Loaning & 12 & 8 & $<6,000,000$ & 12 & 8 \\
\hline Sex & & & $6,000,000-8,000,000$ & 59 & 34 \\
\hline Male & 125 & 73 & $8,000,000-10,000,000$ & 87 & 50 \\
\hline Female & 47 & 27 & $10,000,000-12,000,000$ & 14 & 8 \\
\hline Age & & & Background (year) & & \\
\hline$<25$ & 13 & 7.5 & $<5$ & 25 & 14 \\
\hline $26-30$ & 54 & 31.4 & $5-10$ & 77 & 45 \\
\hline $31-35$ & 68 & 39.5 & $10-15$ & 47 & 27 \\
\hline $36-40$ & 23 & 13.4 & $15-20$ & 10 & 6 \\
\hline$>40$ & 14 & 8.0 & & & \\
\hline
\end{tabular}

\subsection{One sample T-test results}

Table 3 shows mean, std. deviation, and variance of all items existed in questionnaire. Within them, "help to co-workers that get into difficulty" and "trust to co-workers expertise" have the highest means among all items. It is important to note that these two items belong to "trust" variable. It is resulted that trust play a critical role in knowledge sharing activities of employees. Therefore, as focused in literature, creation of trust and collaboration atmosphere in organization is a key way to facilitate knowledge stream between different sections of organization.

Table 3

Descriptive statistics for all items of questionnaire

\begin{tabular}{|c|c|c|c|c|c|c|c|c|c|}
\hline Items & $\begin{array}{c}\mathrm{N} \\
\text { Valid } \\
\end{array}$ & Mean & $\begin{array}{c}\text { Std. } \\
\text { Deviation }\end{array}$ & Variance & Items & $\begin{array}{c}\mathrm{N} \\
\text { Valid } \\
\end{array}$ & Mean & $\begin{array}{c}\text { Std. } \\
\text { Deviation }\end{array}$ & Variance \\
\hline KS1 & 171 & 0.579 & 1.105 & 2.657 & OS1 & 171 & 2.84 & 1.177 & 2.345 \\
\hline KS2 & 171 & 2.84 & 1.925 & 3.925 & OS2 & 171 & 2.75 & 1.463 & 2.139 \\
\hline $\mathrm{KS} 3$ & 171 & 3.12 & 1.784 & 2.748 & OS3 & 171 & 2.91 & 1.471 & 2.163 \\
\hline KS4 & 171 & 3.53 & 1.705 & 2.705 & EA1 & 171 & 2.78 & 1.566 & 2.453 \\
\hline KS5 & 171 & 3.35 & 1.793 & 3.793 & EA2 & 171 & 2.71 & 1.650 & 2.723 \\
\hline $\mathrm{OC} 1$ & 171 & 3.61 & 1.836 & 2.836 & EA3 & 171 & 3.23 & 1.360 & 1.851 \\
\hline $\mathrm{OC} 2$ & 171 & 2.94 & 1.030 & 1.030 & EA4 & 171 & 3.13 & 1.545 & 2.388 \\
\hline OC3 & 171 & 3.52 & 1.870 & 2.870 & EA5 & 171 & 3.64 & 1.532 & 2.348 \\
\hline MM1 & 171 & 3.56 & 1.895 & 2.895 & $\mathrm{~T} 1$ & 171 & 2.84 & 1.832 & 3.357 \\
\hline MM2 & 171 & 3.61 & 1.890 & 3.890 & $\mathrm{~T} 2$ & 170 & 3.64 & 1.645 & 2.706 \\
\hline MM3 & 171 & 3.77 & 1.970 & 2.970 & T3 & 171 & 3.93 & 1.836 & 3.372 \\
\hline MM4 & 171 & 3.65 & 1.008 & 3.008 & $\mathrm{~T} 4$ & 171 & 3.75 & 1.873 & 3.507 \\
\hline MM4 & 170 & 2.72 & 1.126 & 2.054 & & & & & \\
\hline
\end{tabular}


As shown in Table 4, descriptive analysis of data indicated that the most mean belongs trust (3.5382) with standard deviation 1.63835 and OS has the least mean (2.8343). According to Abrams et al. (2003, p. 65) trust helps increase overall KS, makes knowledge exchanges less expensive, and increases the possibility that knowledge acquired from a colleague is sufficiently understood and absorbed that a person can put it to use. KS has the mean value of 3.0842 and standard deviation of 0.44502 with this, it is thus proven that KS are critically dominant in influencing $\mathrm{KS}$ since it is accepted by management practitioners because of its intuitive logic and clear delineation of knowledge types between tacit and explicit (Rice \& Rice, 2003).

Table 4

Descriptive statistics

\begin{tabular}{ccccc}
\hline Variables & $\mathrm{N}$ & Mean & Std. Deviation & Std. Error Mean \\
\hline KS & 171 & 3.0842 & 0.44502 & 0.03403 \\
OC & 171 & 3.2281 & 0.71169 & 0.05442 \\
MM & 170 & 3.4612 & 0.74613 & 0.05723 \\
OS & 171 & 2.8343 & 1.17177 & 0.08961 \\
EA & 171 & 3.1018 & 1.34748 & 0.10304 \\
T & 170 & 3.5382 & 1.63835 & 0.12566 \\
\hline
\end{tabular}

To examine the significance of the variables, a t-test has been used. To assess the significance of the research variables, an introductory test was used. This test examined $\mathrm{H}_{0}$ and $\mathrm{H}_{1}$ in the following way:

1) $\mathrm{H}_{0}: \mu \leq 3$

2) $\mathrm{H}_{1}: \mu>3$

As we can observe from the results of Table 5, all of variables are significant with $(\operatorname{sig}<0.5)$. For analyzing hypotheses, we must take into account the mean of each variable. Among research variables, only organizational structure mean (2.8343) did not desirable desired minimum value of 3. Therefore, $\mathrm{H}_{3}$ is rejected ( $\left.\mathrm{t}=-1.849\right)$. Based on research findings, managers of organizations can enhance their employees' knowledge sharing activities through improve structure of workflow among units. As Zheng et al. (2010) pointed out, Structure can influence knowledge management processes through shaping patterns and frequencies of communication among organizational members, stipulating locations of decision-making, and affecting efficiency and effectiveness in implementing new ideas. They can restructure their organization alignment with knowledge management principles. Other hypotheses, namely $\mathrm{H}_{1}, \mathrm{H}_{2}, \mathrm{H}_{4}, \mathrm{H}_{5}$, and $\mathrm{H}_{6}$ were supported by analysis of data gathered from population. As obtained in previous surveys, factors including organizational culture (e.g. Jiacheng et al., 2010), motivation method (e.g. Quigley et al., 2007), employee's attitude (e.g. Lin, 2007), and trust (e.g. Renzl, 2008) have remarkable impact on knowledge and experience sharing in this investigation as well.

Table 5

One-sample $\mathrm{t}$ test for each hypothesis (test value $=3$ )

\begin{tabular}{ccccccc}
\hline & & & \multicolumn{5}{c}{ Test Value=3 } \\
\cline { 2 - 7 } & \multirow{2}{*}{ t-value } & df. & Sig. (2-tailed) & Mean difference & 95\% Confidence Interval of the Difference \\
\cline { 6 - 8 } & & & & & Lower & Upper \\
\hline KS & 2.474 & 170 & 0.014 & 0.08421 & 0.170 & 0.1514 \\
OC & 4.191 & 170 & 0.000 & 0.22807 & 0.3482 & 0.3355 \\
MM & 8.059 & 169 & 0.000 & 0.46118 & -0.3426 & 0.5741 \\
OS & -1.849 & 170 & 0.069 & -0.16569 & -0.1017 & 0.0112 \\
EA & 0.987 & 170 & 0.325 & 0.10175 & 0.2902 & 0.3052 \\
T & 4.283 & 169 & 0.000 & 0.53824 & 0.7863 \\
\hline
\end{tabular}

\section{Conclusion}

Knowledge has been recognized as the most important factor in determining the survival of organizations. It is therefore difficult, but not impossible, to maximize the value of knowledge by adequately understanding how to leverage and share knowledge in organizations. In this paper, we 
identified some factors, which impact on KS among employees and different units of organization. We attempted to analyze more momentous factors mentioned in knowledge management literature including trust, organizational culture, employee's attitude, motivation method, and organizational structure. Among these factors, organizational structure has less mean value. It is resulted that $\mathrm{H}_{3}$ was not supported in this research. It is shown that managers must restructure their organization and consider routs of knowledge flow. It seems that centralized structure of studied financial organizations may play important role as a barrier for KS. The results have also indicated that a decentralized structure encourages communication and increases employee satisfaction and motivation. In a similar vein, despite inconclusive findings regarding the relationship between organizational structure and knowledge management (Tsai, 2002), a decentralized structure has often been seen as facilitative to knowledge management success (Damanpour, 1991). The results of the study underscore that trust - or lack of it - can have serious implications for organizations. While managers often struggle to figure out the value of the "soft stuff" associated with knowledge management, the results of this study clearly highlight the importance of trust in enabling effective KS. As a result, promoting an environment in which employees have the opportunity to develop both competence- and benevolence-based trust needs to be a central part of an organization's knowledge management agenda. Managers can affect the extent to which trust is developed among employees. The following list presents some actions that managers can take to help build trust among individuals,

- Create a common understanding of how the business works,

- Demonstrate trust-building behaviors,

- Bring people together (Levin, 2002).

In order for the banking institutions to complete leverage their knowledge potential, they must first appreciate and look forward to the enablers, which influence KS as a whole. It is therefore anticipated that this study will eventually facilitate and help the banking sector as a whole in better recognizing and understanding the influencing factors that further induce KS among banks. As a consequence, different researchers and banking sector are able to include and further incorporate the factors investigated in this paper in more enhancing the dominance and power of banking knowledge. Banking institutions in general can also apply the factors and KS presented in this study as a guideline to achieve competitive advantages in their KM implementation.

\section{References}

Abili, K., Thani, F. N., Mokhtarian, F., \& Rashidi, M. M. (2011). The role of effective Factors on Organisational Knowledge Sharing. Procedia - Social and Behavioral Sciences, 29,1701 - 1706.

Abrams, L.C., Cross, R., Lesser, E., \& Levin, D.Z. (2003). Nurturing interpersonal trust in knowledge-sharing networks. Academy of Management Executive, 17(4), 64-77.

Al-Alawi, A.I., Al-Marzooqi, N.Y., \& Mohammed, Y. F. (2007). Organisational culture and knowledge sharing: critical success factors, Journal of Knowledge Management, 11(2), 22-42.

Bock, G.-W., Lee, J.-N., \& Zmud, R. W. (2005). Behavioral intention formation in knowledge sharing. MIS Quarterly, 29(1), 87-111.

Boer, N. Berends, H, Baalen, P.V., (2011), Relational models for knowledge sharing behavior, European Management Journal., 29, 85-97.

Boh, W. F. (2007). Mechanisms for sharing knowledge in project-based organizations. Information and Organisation, 17, 27-58.

Cabrera, A., \& Cabrera, E. F. (2002). Knowledge-sharing dilemmas. Organisation Studies, 23(5), 687- 710 .

Chen, S.S., Chuang, Y.W., \& Chen, P.Y., (2012), Behavioral intention formation in knowledge sharing: Examining the roles of KMS quality, KMS self-efficacy, and organisational climate, Knowledge-Based Systems, doi:10.1016/j.knosys.2012.02.001 .

Cowan, R., David, P., \& Foray, D. (2000). The explicit economics of knowledge codification and tacitness. Industrial and Corporate Change, 9(2), 211-253. 
Damanpour, F. (1991), Organizational innovation: a meta-analysis of effects of determinants and moderators. Academic Management Journal, 34(3), 555-90.

Davenport, T. H., \& Prusak, L. (1998). Working Knowledge: How Organisation Manage What They Know. Harvard Business School Press.

Du, R., Ai, S., \& Ren, Y. (2007). Relationship between knowledge sharing and performance: A survey in Xi'an, China. Expert Systems with Applications, 32, 38-46.

Fishbein, M., \& Ajzen, I. (1981). On construct validity: a critique of miniard and Cohen's paper. Journal of Experimental Social Psychology, 17, 340-350.

Fishbein, M., \& Ajzen, I. (1975). Belief, Attitude, Intention and Behavior: An Introduction to Theory and Research, Reading. Addison-Wesley, MA.

Gadde, L. E., \& Snehota, I. (2000). Marking the most of supplier relationships. Industrial Marketing Management, 29, 305-316.

Grant RM. (1996), Toward a knowledge-based theory of the firm. Strategic Management Journal.,17 (Winter Special Issue):109-22.

Hair, J.F., Anderson, R.E., Tatham, R.L., \& Black, W.C. (2004). Multivariate data analysis (6a ed.). Upper Saddle River, NJ: Pearson-Prentice Hall.

Hislop, D. (2003). Linking human resource management and knowledge management via commitment: a review and research agenda. Employee Relations, 25 (2), 182-202.

Hofstede, G. (1980). Culture's Consequences: International Differences in Work-related Values. Beverly Hills. California: Sage.

Hong, D. G., Koo, C. H., \& Suh, E. H. (2009). Overcoming barriers of knowledge sharing through communities of practice. A case study of steel company. Korean Journal of Information Systems Review, 11(2), 131-145.

Hong, D., Suh, E., \& Koo, C. (2011). Developing strategies for overcoming barriers to knowledge sharing based on conversational knowledge management: A case study of a financial company, Expert Systems with Applications, 38, 14417-14427.

Huang, Q., Davison, R. M., Liu, H., \& Gu, J. (2008). The impact of leadership style on knowledgesharing intentions in China. Journal of Global Information Management, 16(4), 67-91.

Hwang, Y., \& Kim, D. J. (2007). Understanding affective commitment, collectivist culture, and social influence in relation to knowledge sharing in technology mediated learning. IEEE Transactions on Professional Communication, 50(3), 232-248.

Jasimuddin, S. M. (2007). Exploring knowledge transfer mechanisms: The case of a UK-based group within a high-tech global corporation. International Journal of Information Management, 27, 294-300.

Jiacheng, W., Lu, L., \& Francesco, C. A. (2010). A cognitive model of intra-organisational knowledge-sharing motivations in the view of cross-culture, International Journal of Information Management, 30, 220-230.

Jones, M.C., Cline, M., \& Ryan, S., (2006). Exploring knowledge sharing in ERP implementation: An organisational culture framework. Decision Support Systems, 41(2), 411-434.

Kim, W.C., \& Mauborgne, R.A. (1997). Procedural justice, attitudes, and subsidiary top management compliance with multinationals' corporate strategic decisions. Academy of Management Journal., 36(3), 502-26.

Kim, S., \& Lee, H. (2004). Organisational Factors Affecting Knowledge Sharing Capabilities in Egovernment: An Empirical Study. IFIP International Federation for Information Processing, LNAI 3035, 281-293.

Levin, D.Z., \& Cross, R. (2004). The strength of weak ties you can trust: the mediating role of trust in effective knowledge transfer. Management Science, 50, 1477-90.

Levin, DZ, Cross, R., Abrams, L. C., \& Lesser, E.L. (2002). Trust and knowledge sharing: A critical combination. IBM Institute for Knowledge-Based Organizations, 1-10.

Lin, C.P. (2007). To share or not to share: Modeling tacit knowledge sharing, its mediators and antecedents. Journal of Business Ethics, 70, 411-428. 
Lin, W.-B. (2008). The exploration factors of affecting knowledge sharing - the case of Taiwan's high-tech industry. Expert Systems with Applications, 35(3), 661-676.

Moller, K., \& Svahn, S. (2004). Crossing east-west boundaries-knowledge sharing in intercultural business networks. Industrial Marketing Management, 33(2), 219-228.

Nonaka, I. (1994). A dynamic theory of organisational knowledge creation. Organisation Science, 5(1), 14-37.

O’Donnell, A. (2003). Knowledge sharing. Insurance and Technology, 28(13), 50-58.

Polanyi, M. (1962). Personal knowledge: Toward a post-critical philosophy. New York: Harper Torchbooks.

Quigley, N. R., Tesluk, P. E., Locke, E. A., \& Bartol, K. M. (2007). A multilevel investigation of the motivational mechanisms underlying knowledge sharing and performance. Organisation Science, 18(1), 71-88.

Renzl, B. (2008). Trust in management and knowledge sharing: The mediating effects of fear and knowledge documentation, Omega, 36, 206 - 220.

Rice, B.S., \& Rice, J.L. (2003). The applicability of the SECI model to multi-organisational endeavors: An integrative review. International Journal of Organisational Behaviour, 9, 671-682

Saviotti, P. P. (1998). On the dynamics of appropriability, of tacit and of codified knowledge. Research Policy, 26(7-8), 843-856.

Spender, J. C. (1996). Making knowledge the basis of a dynamic theory of the firm. Strategic Management Journal., 17, 45-62.

Subramaniam, M., \& Youndt, M. A. (2005). The influence of intellectual capital on the types of innovative capabilities. Academy of Management Review, 48, 450-463.

Szulanski, G. (1996). Exploring internal stickiness: impediments to the transfer of best practice within the firm. Strategic Management Journal., 17, 27-43.

Tagliaventi, M.R., Bertolotti, F., \& Macrì, D.M. (2010). A perspective on practice in interunit knowledge sharing. European Management Journal., 28, 331- 345.

Takeishi, A. (2001) Bridging inter- and intra-firm boundaries: management of supplier involvement in automobile product development. Strategic Management Journal., 22 (5) 403-433.

Tsai, W. (2002). Social structure of "cooperation" within a multiunit organization: coordination, competition, and intra-organizational knowledge sharing. Organizational Science,13(2),179-90.

Tsai, W. (2000). Social capital., strategic relatedness and the formation of intra-organisational linkages. Strategic Management Journal., 21(9), 925-939.

Tsai, W., \& Ghoshal., S. (1998), Social capital and value creation: the role of intrafirm networks. Academy of Management Journal., 41(4), 464-476.

Wang, Z., \& Wang, N. (2012). Knowledge sharing, innovation and firm performance. Expert Systems with Applications, 39, 8899-8908.

Weir, D., \& Hutchings, K. (2005). Culture embeddedness and contextual constraints: Knowledge sharing in Chinese and Arab cultures. Knowledge and Process Management, 12(2), 89-98.

Xiong, S., \& Deng, H. (2008). Critical Success Factors for Effective Knowledge Sharing in Chinese Joint Ventures. 19th Australasian Conference on Information Systems, 3-5, Christchurch.

Yang, J. T. (2010). Antecedents and consequences of knowledge sharing in international tourist hotels. International Journal of Hospitality Management, 29, 42-52.

Yang, J.T. (2008). Individual attitudes and organisational knowledge sharing. Tourism Management, 29(2), 345-353.

Yao, L.J., Kam, T.H.Y., \& Chan, S.H. (2007). Knowledge sharing in Asian public administration sector: the case of Hong Kong. Journal of Enterprise Information Management, 20(1), 51 - 69.

Zhang, J., Faerman, S.R., \& Cresswell, A.M. (2006). The effect of organisational/ technological factors and the nature of knowledge on knowledge sharing. In: Proceedings of the 39th Hawaii International Conference on System Sciences. IEEE, Hawaii.

Zheng, W., Yang, B., \& McLean, G.N. (2010). Linking organizational culture, structure, strategy, and organizational effectiveness: Mediating role of knowledge management. Journal of Business Research, 63, 763-771. 